\title{
ECONOMIC DEVELOPMENT STRATEGY
}

UDC 330.88(045)

DOI: $10.18372 / 2306-1472.85 .15139$

\section{Mohammad Heydari ${ }^{1}$ \\ Zhou Xiaohu ${ }^{2}$ \\ Kin Keung Lai ${ }^{3}$ \\ Zheng Yuxi ${ }^{4}$}

\section{THE EFFECT OF SYSTEMIC RISK ON CORPORATE RETURNS}

\author{
${ }^{1,2}$ School of Economics and Management, Nanjing University of Science and Technology, Nanjing, Jiangsu, \\ China \\ ${ }^{3}$ College of Economics, Shenzhen University, Shenzhen, China \\ ${ }^{4}$ Faculty of Economics and Management, East China Normal University, Shanghai, China \\ E-mails: ${ }^{1}$ Mohammad_Heydari@njust.edu.cn, ${ }^{2}$ njustzxh@njust.edu.cn, ${ }^{3}$ mskklai@outlook.com, \\ ${ }^{4}$ xyzzoey@126.com
}

\begin{abstract}
Background: This article seeks to complement the previous literature and clarify the risk of an asset is the probable change in the future return on that asset. In another definition, the asset risk is the difference between the actual return on investment and its expected return. Aim: This article seeks to identify the determinants, to find a significant relationship between systematic risk and return on stocks in the Tehran Stock Exchange (TSE) with a method different from conventional econometric methods. Setting: This article examines the time range of, financial information related to the performance of financial years 2012 to 2017 all companies accepted in Tehran Stock Exchange (TSE) that are producers of chemical and detergent materials that their number is 30. Methods: In order to test the hypothesis of the research, we analyze the information on systemic risk and stock returns of two oscillation and low oscillation periods using a discrete wavelet overlapping (DWT) transformation method with a wavelet with a smaller time period using MATLAB software, then to test the research hypotheses Regression analysis has been used to investigate the movement between them. After collecting the information required by the companies, the research hypotheses were analyzed using wavelet analysis and analyzed using SPSS and MATLAB software. Results: Research hypothesis test results indicate a significant relationship between systematic risk and return in periods of high volatility and long-term vision and long term there. Then to test the hypothesis study, regression analysis is used. Research hypothesis test results indicate a significant relationship between systematic risk and return in periods of high volatility and long-term vision and long term there. Conclusion: The results show that there is a meaningful relationship between systemic risk and returns over a period of fluctuation in the medium to long term horizons. In times of low volatility, there is a significant relationship between systemic risk and return on medium-term horizons (94 and 50 days), but only in the long-run horizon of 182 days is a meaningful relationship between risk and return.
\end{abstract}

Keywords: Systematic Risk, Stock Returns, Wavelet Analysis, Daubechies Analysis

\section{Introduction}

In the capital market, one of the most important issues is the relationship between risk and return, especially risk, systematic, since stock returns are believed to be just a function of systemic risk.

Systemic risk in the securities represents a part of the variability in the yield of securities due to the interference of the factors affecting the market set, such as the change in the overall business perspective, which is measured using a criterion called beta. The investor demands more returns when dealing with systemic risk tolerance. An unsystematic risk is an additional risk that it does not have any bearing on the investor and can be greatly reduced or completely eliminated by diversifying its portfolios and creating an investment basket.

Usually, in the economy, and especially in the investment, it is assumed that the investors act reasonably. Investors prefer confidence to uncertainty, and it is natural that in this case investors cannot be risk-averse, in other words, risk averse investors. A risk averse investor is one who, in return for accepting a risk, is expecting a satisfactory return. 
It should be noted that in this case, taking risks is not unreasonable, although the risk is too high, since there is also a high yield expectation. In fact, investors cannot reasonably expect to achieve high returns without high risk taking. On the other hand, research has shown that individuals do not act reasonably and rationally in their decisions under risk conditions [1].

In general, the present research seeks to answer the question: does systemic risk affect the stock returns of companies?

Research questions:

1. Is there a significant relationship between systemic returns and risk in the mid-term horizons of fluctuating periods?

2. Is there a significant relationship between systemic returns and risk in the long-term horizons of the fluctuating periods?

3. Is there a meaningful relationship between systemic returns and risk in the mid-term horizons of low volatility periods?

4. Is there a significant relationship between systemic returns and risk in the long-term horizons of low volatility?

Research hypotheses:

1. There is a significant relationship between efficiency and systemic risk in the mid-term horizons of fluctuating periods.

2. There is a significant relationship between returns and systemic risk in the long run horizons in fluctuating periods.

3. There is a significant relationship between efficiency and systemic risk in the medium-term horizons of low volatility periods.

4. There is a significant relationship between efficiency and systemic risk in the long run horizons in low volatility periods.

\section{Theory}

Risk. Unwittingly, human beings will realize what is going to happen in the future, making the various types of projects a hazardous consequence, therefore, risk may be the likelihood of unfavorable events for the projects being implemented. J.F. Weston and E.F. Brigham write the risk definition of an asset: The risk of an asset is the probable change in the future return on that asset [2]. In another definition, asset risk is the difference between the actual return on investment and its expected return.

Systematic Risk. A common risk definition is that "the term 'risk' denotes the likelihood that an undesirable state of reality (adverse effects) may occur as a result of natural events or human activities" Renn O. (2008), [3]; and Kramm, J. and C. Völker (2018), [4]. A classical risk analysis calculates the possibility of an adverse event and the potential damage, for instance, an assessment of ecotoxicity of hazardous substances based on doseresponse relationships. For "global risks," also termed systemic risks, classical risk analysis is not so easily applicable, since the characteristics of "global risks" comprise complex cause-effect linkages, which are not fully known, resulting in a high degree of uncertainty and ambiguity in assessing the risk. For this reason, consent to risk management strategies is difficult to obtain Wissenschaftlicher Beirat der Bundesregierung Globale Umweltvera“nderungen (1998) and Renn O, Keil F (2008); [3, 8].

It is a part of the risk that affects the general market conditions and affects a large number of assets. Changes in interest rates, the national currency rate against foreign currencies, inflation rates, monetary and fiscal policies, political conditions, etc. are the sources of systematic risk. In this type of risk, changes affect the macroeconomic variables of the entire market [2].

Systematic Risk Index $\boldsymbol{\beta}$. The beta coefficient is considered as a systematic risk indicator that expresses the sensitivity of stock returns to market yields. Using this index, you can examine the rate of return on assets versus the overall market return rate.

Stock returns. Return on equity is defined as the gain on a shareholder's share during the financial period as follows: 1 . Change in price 2. Cash profit of each share 3. Share premium interest 4 . Share-holding benefits Award [6].

With regards to financial time series, stock market time series segmentation is often used for trend analysis, and recent research studies [7-8] have analyzed them movement of a stock based on a selected number of points from the time series. As stated in the work of Gonzalez et al. [9], the relevance of identifying phases in the stock market evolution is quite clear: very few economic phenomena attract more attention than bullish and bearish markets (cycles) do, and there is general agreement that bull markets are associated with persistently rising share prices, strong investor interest and expectations, and enhanced financial well-being [10].

Wavelet analysis. Generally speaking, wavelet analysis is a refined and refined version of Fourier analysis. Before the Fourier analysis, scientists examined the signals (time series) only by studying the time domain. Wavelet analysis is a very effective tool for dealing with the unsteadiness properties of 
time series. The positioning of signals to the desired extent, simultaneous display of multiple scales and is also one of the reasons for using a wavelet [11].

Previously Fourier analysis is used seismic analysis which is ideal for the data that depends only on frequency domain but not on time domain. For the cases, where time-frequency analysis is required wavelets are very much useful. Most of the models in the field of science and Engineering involve the Ordinary Differential Equation (ODE) and Partial Differential Equation (PDE). The accuracy of the result of the models depends upon the solution of the differential equation. The differential equation may be exact or may not be exact, in which case we find a numerical solution. Different numerical methods exist like Picard's Method, Euler's Method, RungeKutta Method to name a few. They are very useful but old methods. Some recent methods are based on wavelets [12-18].

Wavelets are squarely integrable functions that satisfy an admissibility condition [19-22]. The collection of its dilations and translations decompose the space $L^{2}(\mathrm{R})$ orthogonally. Some important wavelet methods developed so far are Chen-Hsiao (1997) [13, 23], Segmentation method [24], Collocation method [16], Filter bank method [25], Operational Matrix method [13, 18]. In [13], operational matrix was introduced. They are developed by integrating the Haar wavelets ${ }^{1}$ and are useful to solve both Ordinary Differential Equations (ODE) and Partial Differential Equations (PDE).

\section{Literature reviews}

Penn and Taylor (1991); [27], similar to the research by Chen et al. (1986) in the UK market [28]. The results of their research showed that macroeconomic variables do not affect stock returns in the UK. This conclusion was contrary to Chen's findings in the American stock market. Penn and Taylor argue that their different conclusion is that either other macroeconomic factors have had an impact on UK stock returns or that the research method used by Chen et al. Was ineffective.

In the 1960s, Sharpe and Lintner provided a model for evaluating risk assets, in which return on assets was a function of risk [29]. They proved that in an

\footnotetext{
${ }^{1}$ Haar Wavelets: Let $m=2 j, j=0,1, \ldots J, k=0,1, \ldots m$ -1 and $i=m+k+1$. Here, $i$ denotes wavelet number, $j$ denotes the level of wavelet and $k$ denotes the translation parameter. $J$ denotes the maximum resolution. The minimum value of $i=2$ and maximum value is $2 M$; [26].
}

efficient market, if the portfolio of an investor is sufficiently diversified, its return is a linear function of its systemic risk. The hypothesis has been tested in many countries, including Iran, using econometric methods and has been approved in most cases.

Blommestein HJ, Turner P in 2012 in their study, the study of the effect of volatility and their combined effect on the relationship between systemic risk and returns, in the 2012 study, has shown that in markets with less volatility, there is a stronger relationship between systemic risk returns [30].

As noted by He and Xiong (2012), a firm faces rollover risk of not being able to roll over matured short-term debt with the issuance of new short-term debt [31]. ${ }^{2}$ They also argue that the firm's rollover risk is affected by debt maturity because the rollover losses of all bonds with short term aureity at a certain date causes equity holder to suddenly absorb rollover losses, and the effect of debt maturity on rollover risk is magnified by the degree of market liquidity.

In the model of Acharya et al. (2011), a sudden "market freeze" phenomenon, which refers to a situation in which a sudden collapse of firms' ability to borrow short term, causes the firms to fail to rollover their short-term debt [31]. The collapse of short-term debt markets (e.g., interbank markets) is arguably considered to be one of the key drivers of the 2007-2008 global financial crisis [31, 33].

Rollover risk typically increases with systemic risk. According to Allen, Babus, et al. (2012), the term "systemic risk" traditionally refers to (1) a situation in which a large number of financial institutions (e.g., banks) fail due to a common stock or a contagion process, (2) the connections between financial institutions, and (3) financial institutions' funding maturity [34].

Schotter and Yorulmazer (2009) note that many static two-period models on bank runs view a bankrun problem as an equilibrium selection problem and focus the analysis on whether in the presence of a probability of a run on a bank, deposit contracts are optimal arrangements. Therefore, they develop a dynamic four-period bank-run model that focuses on the dynamics and severity of bank runs [35]. One of the key insights resulting from their model is that money stays longer in the banking system in the

\footnotetext{
${ }^{2} \mathrm{He}$ and Xiong (2012) note that the firm may suffer rollover losses when the value of new debt issuance is less than the value of them maturing debt, which may affect the value of existing equity [31].
} 
presence of insider information (i.e. those who are informed about the soundness of the banks); that is, withdrawals tend to be made later when there are insiders, relative to when there is no insider.

López-Espinosa, Moreno, Rubia, and Valderrama (2012) find that short-term wholesale funding determines a bank's contribution to systemic risk, and that banks with high levels of short-term funding are more interconnected to other banks and more vulnerable to changes in market conditions and liquidity risk [36].

Furthermore, Uhde and Michalak (2010) show that the variation in European banks' systemic risk can be explained by credit risk securitization [37].

In the model of Allen, Babus, et al. (2012), when banks use long-term debt, the welfare is not affected by the asset structure of the banks, but when shortterm debt is used, the asset structure affects systemic risk [34]. The differential effect of the asset structure on systemic risk is attributed to a signal of banks' future insolvency that investors receive at the intermediate date. When investors detect a signal of banks' future insolvency ${ }^{1}$, they do not roll over the short-term debt, forcing all banks into early liquidation of their assets. In this context, systemic risk in the banking system is due to the banks' failure to roll over their short-term debt. In summary, theoretical and empirical evidence suggest that the level of systemic risk in the banking system increases with banks' rollover risk, indicating the contribution of bank funding maturity to a country's bank systemic risk.

\section{Methodology}

The research method is descriptive in terms of the level of control of the research variables, because we do not have the ability to manipulate the data. For the purpose of the present study, this is an applied study, aimed at gaining the understanding or knowledge necessary to determine the means by which the identified need is resolved. In other words, the purpose of this research is the discovery of new knowledge that follows the proper application of a product or process in reality. The characteristic of an applied research is that the actual information and statistical methods used to reject or not reject the hypotheses are used. Also, the time range of the research, financial information related to the performance of financial years 2012 to 2017 all companies accepted in Tehran Stock Exchange (TSE) that are producers of chemical and detergent materials that their number is 30 . Since the time series data of the research for the years 2012 to 2017, the method of data collection is based on the statistics of Tehran Stock Exchange. The library data has been used to formulate theoretical foundations and research framework.

The research sample is determined by the method of knockout after applying the following assumptions:

1. According to the information required since 2012, the companies that have been accepted in Tehran Stock Exchange (TSE) until the end of 2012 and their names have not been removed by the end of 2017 from the list of listed companies.

2. During the period in question, their shares are actively traded on the stock exchange.

3. In order to increase the comparability of the companies surveyed, their financial period should end on March 20th and should not have a change in the period of the financial year.

4. It is not part of financial intermediation companies (investment, holding, leasing, banks and insurance) because of their different performance.

5. The required information is available.

The general method for determining the statistical sample is as follows (Table 1):

The general method for determining the statistical sample

Table 1

\begin{tabular}{|c|c|}
\hline Explanation & Number of companies \\
\hline All companies accepted on the exchange on 20/March/2017 & 62 \\
\hline Companies that were admitted to the exchange after 2012. & 23 \\
\hline Companies whose fiscal year does not end on March 20 or change the fiscal year. & 2 \\
\hline Financial intermediation companies (investment, holding, leasing and banks) & 7 \\
\hline The total statistical sample is testable with regard to the assumptions & 30 \\
\hline
\end{tabular}

\footnotetext{
${ }^{1}$ An investor's decisions are influenced by (1) information contagion, where news regarding one financial firm's problem(s) is correlated with negative shocks at other financial institutions because they are exposed to common
}

risk factors, or (2) counterparty contagion, where one financial firm's trouble directly causes other financial institutions' problems (see e.g., [38]). 


\subsection{Research model}

The mathematical model of the research is as follows separately, for each of the fluctuating and low volatility periods, and for distinguishing between mid-term and long-term periods.

$$
S R_{i t}=a_{i t}+\beta_{i t}+e_{i t},
$$

where

$a_{i t}$ - the width of the origin of the regression line; $\beta_{i t}$ - systematic risk in $i$ company of the period $t$; $S R_{i t}$ - ordinary stock returns in $i$ company of the period $t$;

$e_{i t}-$ stock return error in $i$ company of the period $t$. risk.

Independent variable of this research is systematic

Systematic Risk is part of the risk that affects the general market conditions and affects a large number of assets. Changes in interest rates, the national currency rate against foreign currencies, inflation rates, monetary and fiscal policies, political conditions, etc. are the sources of systematic risk. In this type of risk, changes affect the macroeconomic variables of the entire market [2].

The systemic risk is calculated by the following regression equation:

$$
R_{i t}=a_{i t}+\beta_{i} r_{m t}+e_{i t},
$$

where

$a_{i t}$ - the width of the origin of the regression line; $R_{i t}$-ordinary stock returns in $i$ company of the period $t$;

$r_{m t}$ - portfolio market returns of the period $t$; $e_{i t}-$ stock return error in $i$ company of the period $t$.

Return on equity is defined as the gain for a shareholder during the financial period as follows: 1 - Change in price; 2 - Cash profit of each share; 3 Advances from the right to purchase shares; 4 Benefit from profit;5 - Shares or shares of the prize [6].

In order to calculate the stock returns, different formulas are presented for different states, which are used in the present study using the following two formulas:

$$
\begin{aligned}
& R_{1}=\frac{D_{t}+p_{t}(1+a+\beta)-\left(p_{t-1}+c a\right)}{p_{t-1}+c a} * 100 ; \\
& R_{2}=\frac{\left[\left(D_{t}+p_{t}\right)(1+a+\beta)\right]-\left(p_{t-1}+c a\right)}{p_{t-1}+c a} * 100,
\end{aligned}
$$

where
$R_{1}$ - stock returns are in the form of an increase in capital after the approval of the profit (holding of the assembly);

$R_{2}$ - stock returns are in the form of an increase in capital before the approval of the profit (holding of the assembly);

$D_{t}-$ dividend payment;

$a$ - percentage increase in capital from claims and cash deposits;

$\beta$ - percentage increase in capital from the reserve location;

$C$ - the nominal amount paid by the investor for raising capital from the place of cash and receivables; $p_{t}$ - share price at the end of period $t$;

$p$-share price at the the beginning of period $t$.

\subsection{Wavelet analysis}

A wavelet can be compared to a lens of a camera, which allows for the capture of large landscape images, and focuses on very tiny detail hidden in the human's eyes. In mathematical terms, wavelets are local orthonormal bases of a wave consisting of divisions that divide a function into layers of varying scales [39].

\subsection{Fourier transform}

Fourier transform converts a signal (time series) using a series of mathematical transformations from the time domain to the frequency spectrum. Fig. 1 illustrate an example of Fourier transforms. The converted signal tells us how much frequency and how much energy of any frequency is in the raw signal, but does not provide us with time information (not telling which part of the time this frequency appears). If the signal is stable, we do not have access to information on the time of the rise of the frequency, but in the real world, most data, especially financial and financial data, are unstable.

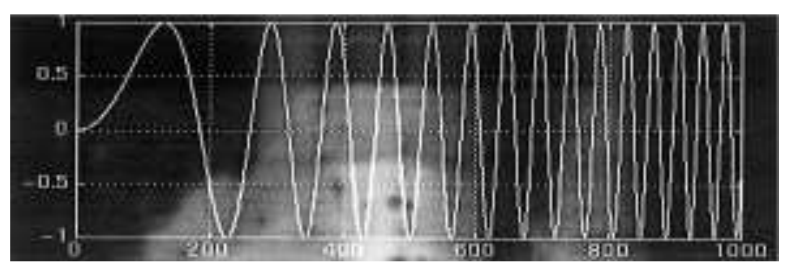

Fig. 1. An example of Fourier transforms

In 1807, the French mathematician, Joseph Fourier, proved that any alternating function with periodicity $(2 \pi)$ can be expressed as a set of sinuses and cousins. The Fourier series and its rates are obtained using the following formula [40-42]. 


$$
f(x)=\frac{a_{0}}{2}+\sum_{\mathbb{k}-1}^{\infty}\left(a_{k} \cos (k x)+b_{k} \sin (k x)\right)
$$

We have the following formula:

$$
\begin{aligned}
& b_{k}=\int_{0}^{2 x \int} f(x) \sin (k x) d x ; \\
& a_{k}=\int_{0}^{2 x \int} f(x) \cos (k x) d x .
\end{aligned}
$$

The Fourier transform is as follows using Euler's rule, which states $i=\sqrt{-1} e^{i x}=\cos (x)+i \sin (x)$ that it acts as a bridge between the time domain and the frequency domain.

$$
F(\omega)=\int_{-\infty}^{+\infty} F(x) e^{-i \omega x}
$$

For example, the Fourier transform of the series in Fig. 1 can be seen in Fig. 2. Be careful that in the Fourier transform of the series, it is unclear what frequency content in the series occurs from time to time.

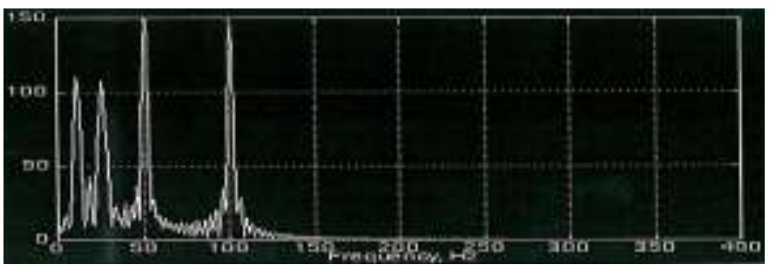

Fig. 2 An example of the Fourier transforms of the series

\subsection{Convert Windows Fourier Transform}

One way to deal with unstable time series before we use a wavelet is to turn the Fourier window. Fourier transforms the window of the signal into equal parts in the time interval. Then each section of the signal is converted, and since the signal is divided into small parts, it can be assumed that the signal in that sector is stable and therefore it is applied to the Fourier transform.

This window function is initially placed at the starting point of the signal, ie the window function is placed at $\mathrm{t}=0$. Then the signal and the window function are multiplied. By doing so, we chose only part of the signal that is as wide as the window. The signal resulting from the multiplication of the window function in its original signal is a new signal that Fourier transformation should apply. If the signal is stable in this width (we assume this is the case), the result of this transformation represents the correct frequency of the main signal in the width of the window.

The next step is to move this window over time to a new position, multiplying the window function in the original signal and applying the Fourier transform to the product of multiplication. This process is repeated to reach the end of the signal. The following formula summarizes the following processes in a single line:

$$
W F T_{X}^{(\omega)}\left(\mathrm{t}^{\prime}, f\right)=\int_{t}\left[x(t) \omega^{*}\left(t-t^{\prime}\right)\right] e^{-i^{2 \times f t}} d t
$$

In the above formula, $X(t)$ is the main signal, $\omega(\mathrm{t})$ the function of the window and the sign * denotes its mixed conjugate. As is clear from the above equation, the Fourier transform of a window is nothing but the Fourier transform, which is multiplied by a Fourier transform coefficient in a window function (see Fig. 3), and is calculated for each new value $t$ 'and $f$ for a Fourier transform coefficient of the window.
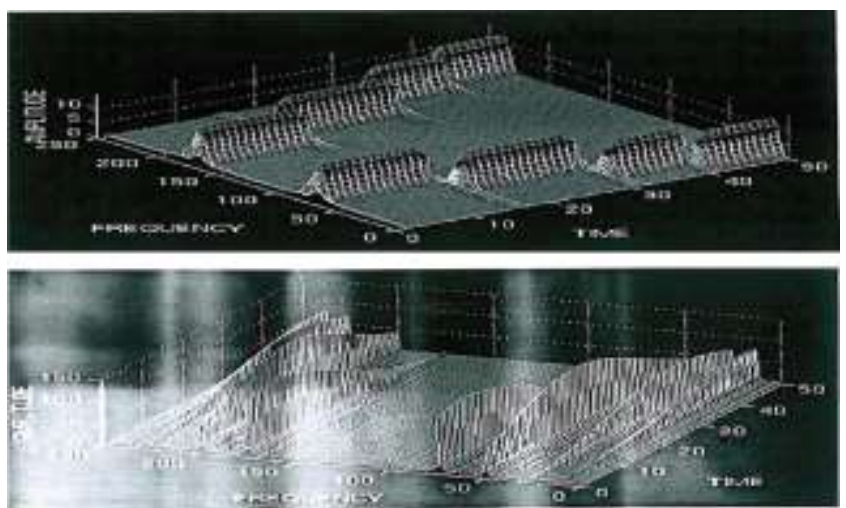

Fig. 3. Examples of the Fourier transform of the window

\subsection{Continuous Wavelet Transform}

In the transformation of a continuous wavelet, a special wavelet is used, which is like the window function in the Fourier transform of a window with special properties. There are two main differences between continuous wavelet transform and Fourier transform. The first difference is that continuous wavelet transformation uses wavelet functions instead of sinusoidal and cousin functions, which makes it possible for us in the signal to get more information about the local oscillations. The second difference, which is more important, is that the width of the window varies in different frequencies. Like the Fourier transform, the main signal in the window function is multiplied and then integrated over time. In short, a function wavelet function of time follows the following rule, which is called the acceptance condition:

$$
C_{\psi}=\int_{0}^{\infty} \frac{\psi(f)}{f} d f \prec \infty
$$


This condition ensures that when the $f \rightarrow 0$ desire, also $\psi(f)$, it's fast approaching zero. In fact, to ensure that $C_{\psi} \prec \infty$ We must impose this condition $\psi(0)=0$ Which is equivalent to:

$$
\int_{-\infty}^{+\infty} \psi(t) d t=0
$$

The second condition that applies to the wavelet function is the unit's energy, and according to the definition of the energy of a function, is the integral of the squared function in its domain:

$$
\int_{-\infty}^{+\infty}|\psi(t)|^{2} d t=1
$$

The continuous wavelet transforms (CWT) is a function of two variables $S$ and $U$, and simply multiplies the multiplication of the function in the wavelet function and the integral from the multiplication product (see Fig. 4). If we assume that the function $X(t)$ is a function of time, its wavelet transform is as follows:

$$
W(u, s)=\int_{-\infty}^{+\infty} x(t) \psi_{u, t}(t) d t
$$
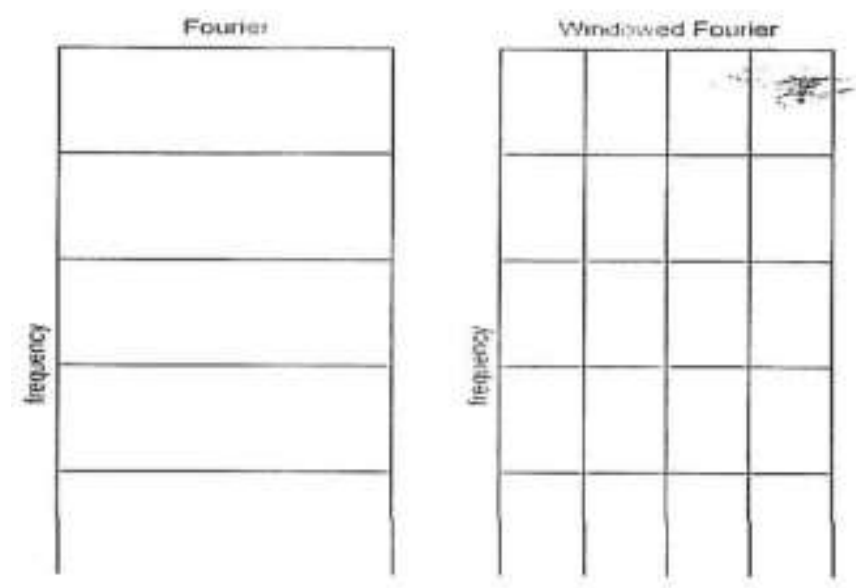

In which $\psi_{u, t}(t)=\frac{1}{\sqrt{s}} \psi\left(\frac{t-u}{s}\right)$ In fact, it is the elementary wavelet function, which is expanded with $s$ size and moved to the size of $u$ at the time axis. The resulting coefficients are actually a function of the two parameters $s$ (scale) and $u$ (the amount of displacement in time). Although the main function is only a function of a parameter, it is also time. In the following figure, you see the continuous wavelet transform of a given series. Note that in this conversion, contrary to the Fourier transform, the frequency used is inversely proportional to the scale used. It is also worth noting that in this conversion, accuracy in time is higher in higher, lower and lower scales.

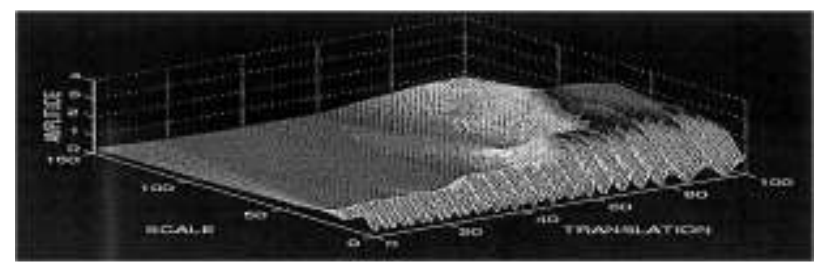

Fig. 4. An example of continuous wavelet transforms

In the following, compare the Fourier transform, the Fourier transform, and the wavelet transform (shown in Fig. 5).

Fig. 5. Comparison of how the time, frequency (time, scale) section divided into three wavelet transforms, Fourier and Fourier window

By dividing the various mother waves (which are moved and dilated in the axis of time), we divide the complex structure function into functions into smaller components. This is called analytics or function analysis. If the wavelet functions used in analyzing the wavelet acceptance condition can be obtained by using the following formula or reverse operation on the wavelet coefficients to the main function:

$$
x(t)=\frac{1}{c_{\psi}} \int_{0}^{\infty} \int_{-\infty}^{\infty} W(u, s) \psi_{u, s}(t) d u \frac{d s}{2}
$$

This is called the synthesis or reconstruction of the function. The key feature of wavelet transforms is that they can be functions integrate the second order completely. By definition, the function $\mathrm{X}(\mathrm{t})$ is the second-order integral if $\int_{-\infty}^{+\infty} x^{2}(t) d t \prec \infty$. 


\subsection{Discrete wavelet transform}

As previously mentioned, continuous wavelet transformation is a function of two parameters and contains a large amount of information that is not required by all of them in the function reconstruction, observation, analysis, and discontinuities. Even if we sample them, that is, the selection of a certain number of scales and discrete movements in time rather than continuous consideration $(s, u)$, we can obtain wavelet coefficients in such a way that they can be reconstructed from the original function. The resulting conversion from the sample $(\mathrm{s}, \mathrm{u})$ is called a discrete wavelet transform (DWT).

The minimum number of sampling from the Nyquist rule is called the critical sampling:

$$
\begin{aligned}
& s=2^{-j} ; \\
& u=k 2^{-j} .
\end{aligned}
$$

In which $(k, j)$ are integers that represent the set of discrete momentum movements in the discrete time and discrete ones. If we consider the power bases of two like the above, in order to change the scale, but to take all the correct values in time, we will achieve the wavelet transform with maximum overlap.

$$
\begin{aligned}
& s=2^{-j} ; \\
& u=k .
\end{aligned}
$$

The approximation of any discrete function or time series using the wavelet functions is obtained as follows:

$$
\begin{aligned}
& f=\sum s j, k \phi_{j, k}(t)+\sum d_{j, k} \psi_{j, k}(t)+ \\
& +\sum d_{j-1, k} \psi_{j-1, k}(t)+\ldots+\sum d_{1, k} \psi_{1, k}(t)
\end{aligned}
$$

In the above formula, $\mathrm{j}$ is the number of analytic levels or scales, and $\mathrm{k}$ the amount of time shift in each level. The functions $\psi, \phi$ of the orthogonal functions of the wavelet are defined as:

$$
\begin{aligned}
\phi_{j, k} & =2^{-\frac{j}{2}} \phi\left(\frac{t-2^{-j} k}{2^{j}}\right) ; \\
\psi_{j, k} & =2^{-\frac{j}{2}} \psi\left(\frac{t-2^{-j} k}{2^{j}}\right) .
\end{aligned}
$$

In the above relations, the $\phi_{j, k}$ wavelet is called the wavelet of the father and the $\psi_{j, k}$ wavelet called the wavelet of the mother. In general, $\phi$ functions are called scalar functions, and $\psi$ functions are called wavelet functions. The wavelet coefficients are obtained from the following relationships:

$$
\begin{aligned}
s_{j, k} & =\int x(t) \phi_{j, k}(t) d t ; \\
d_{j, k} & =\int x(t) \psi_{j, k}(t) d t .
\end{aligned}
$$

Which $s_{j, k}$ are the smooth surfaces of $j$, and $d_{j, k}$ are called the details of the level $j$.

\subsection{Maximal Overlap Discrete Wavelet Transform}

A wavelet transform is the maximal overlap of a modified version of a discrete wavelet transform. The main reason for this correction is that the discrete wavelet transform is sensitive to selecting the starting point of the time series, and this sensitivity is due to the fact that at each step of its application algorithm and the shift in the time axis to the parity and reduction of the sample, part of the information in the sphere of time is lost. In this type of wavelet transform (the Maximal Overlap Discrete Wavelet Transform), the process of reducing the samples does not take place. Moving in the axis of time is done in unit mode and the circular filter is applied, and in contrast to the discrete wavelet transformation, which is divided into two series with half length of the previous step after each step of the original time series algorithm. At each step, the size of the series details and series is smoothly aligned with the original series. In this conversion, the energy of the original time series is maintained. One of the constraints of a discrete wavelet transform is that the number of observations should be a multiple of 2 .

\section{Data analysis}

In order to test the hypothesis of the research, we first divide the research period into two categories of oscillation and low volatility based on the industry index's variability. Then, we analyze the information on systemic risk and stock returns of two oscillation and low oscillation periods using a discrete wavelet overlapping (DWT) transformation method with a wavelet with a smaller time period using MATLAB software, then to test the research hypotheses Regression analysis has been used to investigate the movement between them. To analyze information and test hypotheses, the information required will be collected from the data center of the site www.irbourse.com for a six-year period (2012-2017). After collecting the information required by the companies, the research hypotheses were analyzed using wavelet analysis and analyzed using SPSS and MATLAB software.

Given the symmetry of the time series data studied and the condition $2^{\wedge} j \leq N$ In order to determine the levels that can be decomposed into discrete wavelet data and the number of data, 93 data for fluctuating periods and 710 data for low oscillation periods, using a Daubechies wavelet $4(\mathrm{db} 4)$ and using MATLAB 
software, respectively, We analyze the 6th and 9th levels, then separate the data for oscillating and low volatility periods in two mid-term and long-term horizons and test the research hypotheses.

$$
\begin{aligned}
& 2^{\wedge} 9=512512 \prec 710 \prec 10242^{\wedge} 10=1024 \\
& 2^{\wedge} 6=64 \quad 64 \prec 93 \prec 128 \quad 2^{\wedge} 7=128
\end{aligned}
$$

Given the above, the time periods at different levels are represented in Table 2 and Table 3 :

Hight volatility period

Table 2

\begin{tabular}{|c|c|}
\hline Level & Time period \\
\hline Level 1 & 50 days \\
\hline Level 2 & 28 days \\
\hline Level 3 & 17 days \\
\hline Level 4 & 12 days \\
\hline Level 5 & 9 days \\
\hline Level 6 & 8 days \\
\hline
\end{tabular}

Low volatility period

Table 3

\begin{tabular}{|c|c|}
\hline Level & Time period \\
\hline Level 1 & 358 days \\
\hline Level 2 & 182 days \\
\hline Level 3 & 94 days \\
\hline Level 4 & 50 days \\
\hline Level 5 & 28 days \\
\hline Level 6 & 17 days \\
\hline Level 7 & 12 days \\
\hline Level 8 & 9 days \\
\hline Level 9 & 8 days \\
\hline
\end{tabular}

Results of regression analysis in highly volatile periods

\begin{tabular}{|c|c|c|}
\hline Medium term 28 days & Long-term 50-days & Systematic Risk Index (Beta) \\
\hline 0.603 & 0.696 & Sig \\
\hline 0.000 & 0.000 & F \\
\hline 69.124 & 543.541 & R Square \\
\hline 0.190 & 0.679 & \\
\hline
\end{tabular}

Third hypothesis. There is a significant relationship between efficiency and systemic risk in the medium-term horizons during low volatility periods.

According to the number of days of each level, the levels of 3 and 4 (94 and 50 days) were determined as a long-term time interval and according to the results

Fourth hypothesis. There is a significant relationship between efficiency and systemic risk in the long-term horizons of low volatility periods.

Regarding the number of days per level, levels 1 and 2 (358 and 182 days) have been determined as a long-term time interval, and according to the results of Table 5 and the Sig value, it is noted that during the 182-day period, less than 5; in the 358-day period,

\section{Discussion and Conclusion}

In summary, the results of the research hypotheses are as follows:

First hypothesis. There is a significant relationship between efficiency and systemic risk in the mid-term horizons of the fluctuating periods.

Regarding the number of days per level, Level 2 (28 days) is defined as the mid-term interval, and according to the results of Table 4 and the Sig value is less than 5\%, Fisher's (F) statistics can be Stated that there is a meaningful relationship between returns and systematic risk in the mid-term horizons of the fluctuating periods. Consequently, the assumption $\mathrm{H}_{0}$ is rejected and the assumption $\mathrm{H}_{1}$ is confirmed, and finally the first hypothesis of the research is confirmed.

Second hypothesis. There is a significant relationship between efficiency and systemic risk in the long-term horizons of the fluctuating periods.

According to the number of days per level, the level 1 (50 days) is set as a long-term period and according to the results of Table 4 and the Sig value is less than 5\% and Fisher's (F) statistics can be Stated that there is a meaningful relationship between returns and systematic risk in the long-term horizons of the fluctuating periods. Consequently, the assumption $\mathrm{H}_{0}$ is rejected and the assumption $\mathrm{H}_{1}$ is confirmed, and finally the second hypothesis of the research is confirmed.

Table 4

of Table (5) and the Sig value is less than $5 \%$, Fisher's (F) it can be argued that there is a meaningful relationship between returns and systematic risk in the mid-term horizons in low volatility periods. Consequently, the assumption $\mathrm{H}_{0}$ is rejected and the assumption $\mathrm{H}_{1}$ is confirmed, and finally the third hypothesis of the research is confirmed.

it is more than 5 percent. Fisher's (F) statistics can be used to indicate that there is a meaningful relationship between returns and systematic risk in the long-term horizons of the 182-day period. As a result, in the 182-day period, the assumption $\mathrm{H}_{0}$ is rejected and the $\mathrm{H}_{1}$ assumption is confirmed, and in the 358-day period, the assumption $\mathrm{H}_{0}$ is confirmed and the $\mathrm{H}_{1}$ assumption is rejected. 
Results of regression analysis in low volatility periods

\begin{tabular}{|c|c|c|c|c|}
\hline $\begin{array}{c}\text { Medium term 50 } \\
\text { days }\end{array}$ & $\begin{array}{c}\text { Medium term 94 } \\
\text { days }\end{array}$ & $\begin{array}{c}\text { Long term 182 } \\
\text { days }\end{array}$ & Long term 358 days & \multicolumn{2}{|c}{} \\
\hline 0.118 & 0.161 & 0.131 & 0.029 & $\begin{array}{c}\text { Systematic Risk Index } \\
\text { (Beta) }\end{array}$ \\
\hline 0.034 & 0.000 & 0.000 & 0.236 & Sig \\
\hline 4.527 & 16.609 & 21.311 & 1.601 & F \\
\hline 0.014 & 0.033 & 0.020 & 0.003 & R Square \\
\hline
\end{tabular}

The results show that there is a meaningful relationship between systemic risk and returns over a period of fluctuation in the medium to long term horizons. In times of low volatility, there is a significant relationship between systemic risk and return on medium-term horizons (94 and 50 days), but only in the long-run horizon of 182 days is a meaningful relationship between risk and return.

\section{Research suggestions}

Considering the confirmation of the first hypothesis of the research that (there is a significant relationship between systemic returns and systemic risk in the mid-term horizons of the period in the volatile periods), capital market players are recommended to assess and anticipate the future returns of the stock in the volatile periods and with the investment vision of Determine the duration of the systematic risk and consider it as a predictor variable in their model.

Considering the confirmation of the second hypothesis of the research (that there is a significant relationship between systemic returns and systemic risk in the long-term horizons of the volatile periods), it is suggested that the capital market participants in order to assess and anticipate future stock returns in fluctuating and long-term investment visions. Determine the systemic risk and consider it as a predictor variable in their model.

Considering the confirmation of the third hypothesis of the research that (there is a significant relationship between systemic returns and systemic risk in the mid-term horizons of the low volatility horizons), capital market players are recommended to evaluate and anticipate the future return of the stock during periods of low volatility and capital vision Determine the medium-term systematic risk and consider it as a predictor variable in their model.

Considering the confirmation of the fourth hypothesis of the research in the 182-day period (there is a significant relationship between systemic returns and systemic risk in the long-term horizons of low volatility horizons), capital market players are recommended to evaluate and anticipate the future return on equity firms in low volatility periods and with long-term investment vision, determine the systemic risk and consider it as a predictor variable in their model.

\section{References}

[1] Abrazi, Samadi, Timurid (2007). Factors Affecting Risk and Return on Investment in Financial Products. Journal of Trends, pp. 152-123.

[2] Abdo Tabrizi, Radpour M. (2009). Measuring and Managing Market Risk: A Value-At-Exposure Approach. Tehran: Aqa Publication, 426 p.

[3] Renn O (2008). Concepts of risk: an interdisciplinary review. GAIA-Ecol Perspect Sci Soc 17 (1): pp. 50-66.

[4] Kramm, J. and C. Völker (2018). Understanding the Risks of Microplastics: A SocialEcological Risk Perspective. Freshwater Microplastics: Emerging Environmental Contaminants? M. Wagner and S. Lambert. Cham, Springer International Publishing: pp. 223-237.

[5] Wissenschaftlicher Beirat der Bundesregierung Globale Umweltvera"nderungen (1998). Welt im Wandel: Strategien zur Bewa“ltigung globaler Umweltrisiken: Jahresgutachten 1998. Springer, Berlin.

[6] Ghaemi M.A., Neematolahi. (2006). Evaluation of the cost of distribution and sales, general and administrative and cost of goods sold in the manufacturing companies accepted in Tehran Stock Exchange. Journal of Experimental Financial Accounting Studies, 16: pp. 71-90.

[7] Keogh E., Chu S., Hart D., Pazzani M. (2001). An online algorithm for segmenting time series. In: Data mining, 2001. ICDM 2001, Proceedings of the IEEE international conference on. pp. 289-296.

[8] Pratt K.B. (2001). Locating patterns in discrete time-series. PhD Thesis, University of South Florida, Department of Computer Science and Engineering.

[9] Gonzalez L, Powell JG, Shi J, Wilson A (2005). Two centuries of bull and bear market cycles. 
Int Rev Econ Finance 14(4): pp. 469-486.

[10] Durán-Rosal, A. M., et al. (2017). "Identifying Market Behaviours Using European Stock Index Time Series by a Hybrid Segmentation Algorithm." Neural Processing Letters 46(3): pp. 767-790.

[11] Schleicher Ch. (2002). An introduction to wavelets for economists. Bank of Canada working paper, $32 \mathrm{p}$.

[12] Cattani, C. (2001). Haar wavelet splines. J. Interdiscip. Math. 4, pp. 35-47.

[13] Chen, C.F., Hsiao, C.H. (1997). Haar wavelet method for solving lumped and distributed-parameter system. IEE Proc. Control Theory Appl. 144, pp. 87-94.

[14] Comincioli, V., Naldi, G., Scapola, T. (2009). A wavelet based method for numerical solution of nonlinear evolution equations. Appl. Numer. Math. 33, pp. 291-297.

[15] Hsiao, C.H., Wang, W.J. (2001). Haar wavelet approach to nonlinear stiff systems. Math. Comput. Simul. 57, pp. 347-353.

[16] Mehra, M., Kevlahan, N.K.R. (2008). An adaptive wavelet collocation method for the solution of partial differential equation on the sphere. $J$. Comput. Phys. 227, pp. 5610-5632.

[17] Tangborn, A., Zhang, S.Q. (2000). Wavelet transform adapted to approximate Kalman filter system. Appl.Numer. Math. 33, pp. 307-316.

[18] Wu, J.L. (2009). A wavelet operational matrix method for solving fractional partial differential equations numerically. Appl. Math. Comput. 214 (1), pp. 31-40.

[19] Chui, C.K. (1992). An Introduction to Wavelets. Academic Press, Boston.

[20] Daubechies, I. (1992). Ten Lectures on Wavelet. SIAM, Philadelphia.

[21] Daubechies, I. (1990). The wavelet transform time-frequency localization and signal analysis. IEEE Trans. Inf. Theory 36, pp. 961-1005.

[22] Strang, G. (1992). Wavelet transforms versus Fourier transforms, Research Notes, MIT, pp. 1-18.

[23] Chen, C.F., Hsiao, C.H. (1997). Wavelet approach to optimising dynamic systems. IEEE Proc. Control Theory Appl. 146, pp. 213-219.

[24] Lepik, U. (2005). Numerical solutions of differential equations using Haar wavelets. Math. Comput. Simul. 68(2), pp. 127-143.

[25] Walden, J. (1999). Filter bank methods for hyperbolic PDEs. SIAM J. Numer. Anal. 36, pp. 1183-1233.

[26] Lepik, U. (2011). Solving PDEs with the aid of two-dimensional Haar wavelets. Comput. Math. Appl. 61, pp. 1873-1879.
[27] Penn and Taylor (1991). The preferencel Rejection theory also contents that personality characteristics impacts behaviors through preferences.

[28] Chen NF, Roll R, Ross SA (1986). Economic Forces and Stock Market. J. Bus., 59: pp. 383-404.

[29] Sharpe and Lintner (1960). Advanced Asset Pricing Theory - Page xxv.

[30] Blommestein H.J., Turner P. (2012). Interactions between sovereign debt management and monetary policy under fiscal dominance and financial instability.

[31] He, Z., \& Xiong, W. E. I. (2012). Rollover risk and credit risk. Journal of Finance, 67, pp. 391430 .

[32] Acharya, V. V., Gale, D., \& Yorulmazer, T. (2011). Rollover risk and market freezes. Journal of Finance, 66, pp. 1177-1209.

[33] Iyer, R., Peydro, J. -L., da Rocha-Lopes, S., Schoar, A. (2014). Interbank liquidity crunch and the firm credit crunch: Evidence from the 2007-2009 crisis. Review of Financial Studies, 27, pp. 347-372.

[34] Allen, F., Babus, A., \& Carletti, E. (2012). Asset commonality, debt maturity and systemic risk. Journal of Financial Economics, 104, pp. 519-534.

[35] Schotter, A., \& Yorulmazer, T. (2009). On the dynamics and severity of bank runs: An experimental study. Journal of Financial Intermediation, 18, pp. 217-241.

[36] López-Espinosa, G., Moreno, A., Rubia, A., Valderrama, L. (2012). Short-term wholesale funding and systemic risk: A global CoVaR approach. Journal of Banking \& Finance, 36, pp. 3150-3162.

[37] Uhde, A., \&Michalak, T. C. (2010). Securitization and systematic risk in European banking: Empirical evidence. Journal of Banking \& Finance, 34, pp. 3061-3077.

[38] Helwege, J. (2010). Financial firm bankruptcy and systemic risk. Journal of International Financial Markets, Institutions and Money, 20, pp. 1-12.

[39] Moshiri S., Pakhizeh K., Debirian M., Jafari E. 1389 Investigating the relationship between stock return and inflation by using wavelet analysis in Tehran Stock Exchange. Quarterly Journal of Economic Research, 42: pp. 55-74.

[40] Warnatz, K., Salzer, U., Rizzi, M., Fischer, B., Gutenberger, S., Böhm, J., ... \& Schlesier, M. (2009). B-cell activating factor receptor deficiency is associated with an adult-onset antibody deficiency syndrome in humans. Proceedings of the National Academy of Sciences, 106(33), pp. 1394513950. 
[41] Renn O, Keil F (2008) Systemische Risiken: Versuch einer Charakterisierung. GAIA-Ecol Perspect Sci Soc 17(4): pp. 349-354.
[42] Sharp, w.f. \& Aleander, G.J. \& Bailey, J.V. (1995). Investment. New Jersey: prentice - Hall Inc.

\title{
М. Гейдарі ${ }^{1}$, Ч. Сяоху ${ }^{2}$, К. К. Лай ${ }^{3}$, Ч. Юйсі ${ }^{4}$ \\ Оцінка впливу систематичного ризику на прибуток підприємств \\ ${ }^{1,2}$ Нанкінський університет науки і техніки, Нанкін, Цзянсу, КНР \\ ${ }^{3}$ Коледж економіки, Університет Шеньчжень, Шеньчжень, КНР \\ ${ }^{4}$ Східно-китайский педагогічний університет, Шанхай, КНР
}

Постановка проблеми: стаття $є$ доповненням до попередніх публікацій та розглядає питання визначення ризику як ймовірності зміни майбутньої рентабельності активів. В іншому визначенні, ризик активів - це різниця між фактичним прибутковістю інвестицій та очікуваним значенням. Мета: визначити детермінанти, знайти значну залежність між систематичним ризиком та рентабельністю активів на Тегеранській фондовій біржі за допомогою методу, відмінного від звичайних економетричних методів. Вхідні дані: стаття досліджує часовий діапазон фінансової інформації, пов'язаної з результатами фінансових років з 2012 по 2017 рік усіх компаній, прийнятих на Тегеранській фондовій біржі, які виробляють хімічні та миючі матеріали, у загальній кількості 30 компаній. Методи: для того, щоб перевірити гіпотезу дослідження, проаналізовано інформацію про систематичний ризик та прибутковістю активів за два періоди коливань та низьких коливань, використовуючи метод дискретного перетворення вейвлетів з вейвлетом з меншим періодом часу за допомогою програмного забезпечення MATLAB, а потім для тестування гіпотез був використаний регресійний аналіз для дослідження зміни між ними. Після збору необхідних даних компаній, гіпотези дослідження були проаналізовані за допомогою вейвлет-аналізу та проаналізовані за допомогою програмного забезпечення SPSS та MATLAB. Результати: Результати тестування гіпотези дослідження вказують на значну залежність між систематичним ризиком та прибутковістю в періоди високої мінливості та довгострокового існування. Для перевірки гіпотези використовується регресійний аналіз. Результати перевірки гіпотези дослідження вказують на значну залежність між систематичним ризиком та прибутковістю в періоди високої мінливості та довгострокового існування. Висновок: Результати показують, що існує суттєва залежність між системним ризиком та прибутковістю протягом періоду коливань середньо- та довгострокових горизонтів. У часи низької волатильності існує значний взаємозв'язок між систематичним ризиком та рентабельністю на середньострокові горизонти (94 і 50 днів), але лише в довгостроковому горизонті в 182 дні існує суттєва залежність між ризиком і прибутковістю.

Ключові слова: систематичний ризик, прибутковість активів, вейвлет-аналіз, аналіз Добеші

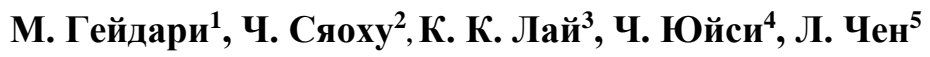 \\ Оценка влияния систематического риска на прибыль предприятий \\ ${ }^{1,2}$ Нанкинский университет науки и техники, Нанкин, Цзянсу, КНР \\ ${ }^{3}$ Коледж экономики, Университет Шэньчжэнь, Шэньчжэнь, КНР \\ ${ }^{4}$ Восточно-китайский педагогический университет, Шанхай, КНР
}

Постановка проблемы: статья является дополнением к предыдущим публикациям и рассматривает вопрос определения риска как вероятности изменения будущей рентабельности активов. В другом определении, риск активов - это разница между фактическим доходностью инвестиций и ожидаемым значением. Цель: определить детерминанты, найти значительную зависимость между систематическим риском и рентабельностью активов на Тегеранской фондовой бирже с помощью метода, отличного от обычных эконометрических методов. Исходные данные: статья исследует временной диапазон финансовой информации, связанной с результатами финансовых лет с 2012 по 2017 год всех компаний, принятых на Тегеранской фондовой бирже, производящих химические и 
моющие материалы, в общем количестве 30 компаний. Методы: для того, чтобы проверить гипотезу исследования, проанализирована информация о систематическом риске и доходности активов за два периода колебаний и низких колебаний, используя метод дискретного преобразования вейвлетов с вейвлетом с меньшим периодом времени с помощью программного обеспечения MATLAB, а затем для тестирования гипотез был использован регрессионный анализ для исследования изменения между ними. После сбора необходимых данных компаний, гипотезы исследования были проанализированы с помощью вейвлет-анализа и проанализированы с помощью программного обеспечения SPSS и MATLAB. Результаты: результаты тестирования гипотезы исследования указывают на значительную зависимость между систематическим риском и доходностью в периоды высокой изменчивости и долгосрочного существования. Для проверки гипотезы используется регрессионный анализ. Результаты проверки гипотезы исследования указывают на значительную зависимость между систематическим риском и доходностью в периоды высокой изменчивости и долгосрочного существования. Вывод: результаты показывают, что существует существенная зависимость между системным риском и доходностью в течение периода колебаний средне- и долгосрочных горизонтов. Во времена низкой волатильности существует значительная взаимосвязь между систематическим риском и рентабельностью на среднесрочные горизонты (94 и 50 дней), но только в долгосрочном горизонте в 182 дня существует существенная зависимость между риском и доходностью.

Ключевые слова: систематический риск, доходность активов, вейвлет-анализ, анализ Добеши

Mohammad Heydari. PhD student. School of Economics and Management, Nanjing University of Science and Technology, Nanjing, Jiangsu, China

E-mail: Mohammad_Heydari@njust.edu.cn

Zhou Xiaohu. Professor. School of Economics and Management, Nanjing University of Science and Technology, Nanjing, China

E-mail: njustzxh@njust.edu.cn

Kin Keung Lai. Professor. College of Economics, Shenzhen University, Shenzhen, China E-mail:mskklai@outlook.com

Zheng Yuxi. PhD student. East China Normal University, Shanghai, China

E-mail: xyzzoey@126.com 